\title{
Interannual Fluctuations of the Tropical Easterly Jet and the Summer Monsoon in the Asian Region
}

\author{
By Minoru Tanaka \\ Institute of Geoscience, University of Tsukuba, Niihari-gun, Ibaraki Pref. 305, Japan \\ (Manuscript received 16 October 1981, in revised form 18 March 1982)
}

\begin{abstract}
Synoptic analysis was conducted of interannual variations of the tropical summer monsoon circulation during the 17 -year period from 1964 to 1980 . The $150 \mathrm{mb}$ wind speed at $10^{\circ} \mathrm{N}\left(40^{\circ} \mathrm{E}-110^{\circ} \mathrm{E}\right)$ were read from the analyzed maps and used to represent the fluctuations of the tropical easterly jet stream (TEJ). The strength of the TEJ was used asi an indicator of the strength of the tropical summer monsoon over Asia $\left(10-30^{\circ} \mathrm{N}, 40-130^{\circ} \mathrm{E}\right)$.

Evidence has been shown that the interannual fluctuations of the summer monsoon are under the strong influence of the middle latitude circulation of the northern hemisphere. When the monsoon is strong, the circulation near $50^{\circ} \mathrm{N}$ is zonal. On the other hand when the monsoon is weak, a blccking high develops to the north of the Caspian Sea and a trough develops near $50^{\circ} \mathrm{N}, 110-120^{\circ} \mathrm{E}$. The Walker circulation plays a smaller role compared to the winter monsoon. However major El Nino years $(1965,1972,1976)$ were found to be the years with weak monsoon.

The 1979 MONEX summer was one with a weak monsoon. Only 3 of the past 17 summers (major El Nino years) had weaker monsoon compared to the MONEX summer.
\end{abstract}

\section{Intorduction}

The tropical easterly jet (hereafter called TEJ) in the upper troposphere is the return flow of the summer monsoon (thermally direct circulation) in the tropical Asian region $\left(10-30^{\circ} \mathrm{N}, 40-\right.$ $120^{\circ} \mathrm{E}$ ). Because the low level monsoon circulation is subject to distortion by the small scale topography, the TEJ is suitable for monitoring the year to year fluctuations of the tropical monsoon circulation.

The TEJ was discovered by Koteswaram (1958) who has analyzed the upper tropospheric circulation during the summer of 1955 over southern Asia and adjacent north Africa. The level of strongest wind was found to be located at the $150-100 \mathrm{mb}$ level. He suggested that there should be a close connection between fluctuations in the upper easterly current and the low level monsoon. The latitude of the core of the jet stream was found to exist near $10^{\circ} \mathrm{N}$ in later investigations using the new data from southern India and the Indian Ocean (Flohn, 1964, Newell et al., 1972, Kobayashi, 1974).
The dynamical analysis of the TEJ was carried out by Keshavamurti (1968). He computed the angular momentum balance in southern Asia and the Indian Ocean north of the equator. It was shown that a mean meridional circulation (which is a direct circulation) maintains the TEJ. Krishnamurti (1971) has computed the $200 \mathrm{mb}$ velocity potential in a period from June to $\mathrm{Au}$ gust 1967 and shown that there exists an ascending warm air over Burma and descending cold air over the oceanic tropics.

In the recent years, Kanamitsu and Krishnamurti (1978) have computed the tropical circulation in the summer of 1967 and 1972. In the drought year of 1972, the tropical circulation in the upper troposphere was displaced some $10^{\circ}$ of latitude to southeast over the Asian monsoon region. In addition, the TEJ was much weaker than the normals.

In the current study, interannual fluctuations of the tropical summer monsoon were analyzed for a 17 year period from 1964 to 1980 (JuneSeptember). The strength of the TEJ at $10^{\circ} \mathrm{N}$ was used as a measure of intensity of the sum- 


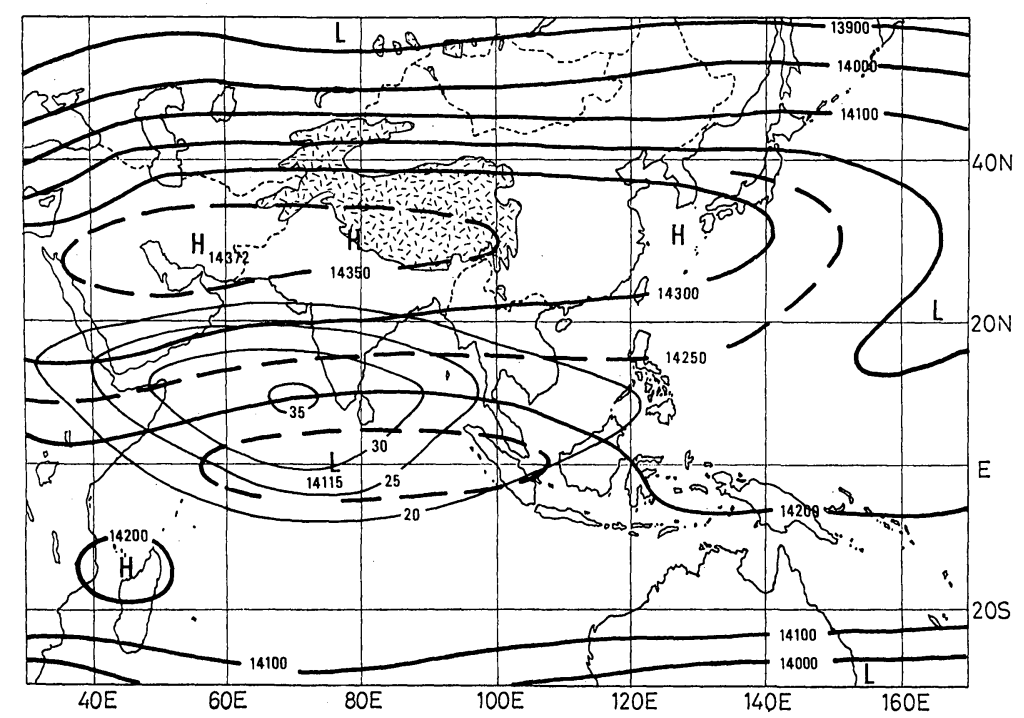

Fig. 1 Mean $150 \mathrm{mb}$ geopotential height in August (1964-1977 average) shown by the thick lines and the isotachs of the TEJ (thin lines). Units are geopotential meters and $\mathrm{ms}^{-1}$ respectively.

mer monsoon. The relationship between the changes in summer monsoon and the distribution of the precipitation was also investigated. The relationship to the middle latitude circulation and the Walker circulation was also analyzed.

\section{Data and methods of synoptic investigation}

The primary source of the data was Monthly Climatic Data for the World published by the NOAA in U.S.A. The upper air data for the People's Republic of China are obtained from the Daily Weather Map published by the Japan Meteorological Agency. In the current study, the data for June to September (1964-1980) covering the area shown in Figure 1 are used from above sources. The precipitation data for People's Republic of China were not available before 1976 .

In every year of the research period, the monthly mean maps of the total precipitation, the $850 \mathrm{mb}$ and $150 \mathrm{mb}$ circulation are drawn for June to September. Figure 1 shows the 150 $\mathrm{mb}$ geopotential height and the isotachs of the TEJ in August. The axis of the strong wind lies near $10^{\circ} \mathrm{N}$ with maximum wind speed of 35 $\mathrm{ms}^{-1}$ near southern India. An inspection of the similar maps at the $100 \mathrm{mb}$ and $200 \mathrm{mb}$ level showed that the TEJ was best observed at the $150 \mathrm{mb}$ level.

The monthly wind speed of the TEJ was obtained by reading from the analyzed maps of the $150 \mathrm{mb}$ level. The wind speed at $10^{\circ} \mathrm{N}$

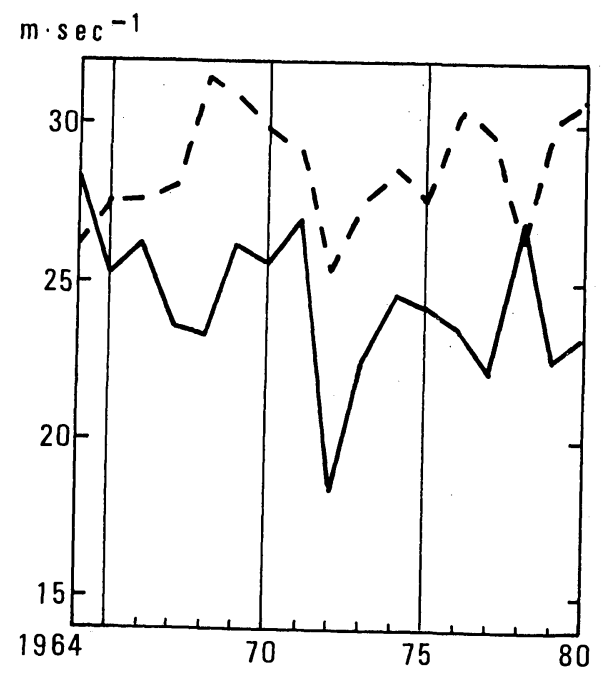

Fig. $2150 \mathrm{mb}$ wind speed at $10^{\circ} \mathrm{N}$ (TEJ) in June (solid line) and July (dashed line) for a period from 1964 to 1980. (Unit: $\mathrm{ms}^{-1}$ )

between the longitude from $40^{\circ} \mathrm{E}$ to $110^{\circ} \mathrm{E}$ were read (every $10^{\circ}$ ) and the average of these eight values was used to represent the strength of the TEJ (monsoon circulation) for a given month.

Figures 2 and 3 show the fluctuations of the TEJ obtained by this method. The fluctuations of the TEJ show a considerable variability from June to July (Figure 2). The interannual variability is smaller in July compared to the other 


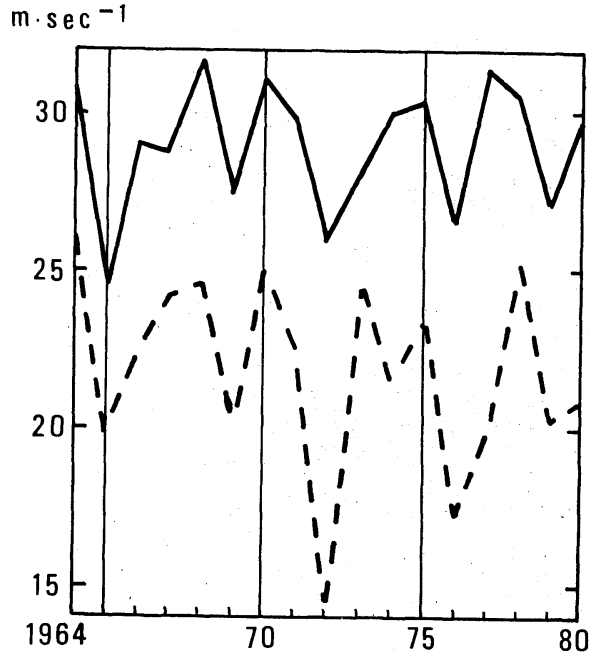

Fig. 3 Same as Fig. 2 but for August (solid line) and September (dashed line).

months.

The relationship between the fluctuations of the TEJ and the low level monsoon circulation (including the precipitation) was investigated by the composite maps. For each of the four months in the summer monsoon season, the composite maps of four years (Table 1) with strong TEJ (weak TEJ) were drawn for the precipitation and the $850 \mathrm{mb}$ and $150 \mathrm{mb}$ geopotential heights. The difference (in the two composite maps) was obtained by subtracting
Table 1 Years used for the composite maps

\begin{tabular}{|c|c|c|c|c|}
\hline Months & June & July & August & September \\
\hline Strong & 1964 & 1968 & 1964 & 1964 \\
\hline \multirow[t]{3}{*}{ TEJ } & 1969 & 1969 & 1968 & 1968 \\
\hline & 1970 & 1970 & 1970 & 1970 \\
\hline & 1971 & 1976 & 1977 & 1978 \\
\hline Weak & 1968 & 1964 & 1965 & 1965 \\
\hline \multirow[t]{3}{*}{ TEJ } & 1972 & 1965 & 1969 & 1972 \\
\hline & 1973 & 1972 & 1972 & 1976 \\
\hline & 1977 & 1975 & 1976 & 1977 \\
\hline
\end{tabular}

the composite map for years of weak TEJ from the map of the same element for strong TEJ.

\section{Relationship between changes in the TEJ and summer monsoon}

Figure 4 shows the difference in the $850 \mathrm{mb}$ geopotential height in June. The positive values show an increases in the geopotential height when the TEJ is strong. The center of decreased geopotential height extends from Saudi Arabia to northern India. When the TEJ is strong, the low level monsoon circulation is intense in most of southern Asia. The wide negative areas in the higher northern latitudes to the north of the Caspian Sea and the Okhotsk Sea suggests a strong interaction between the middle latitude circulation and the TEJ.

Figure 5 shows the difference in the precipitation in June. The positive values (dark shaded regions are over $+50 \mathrm{~mm}$ ) show the heavy pre-

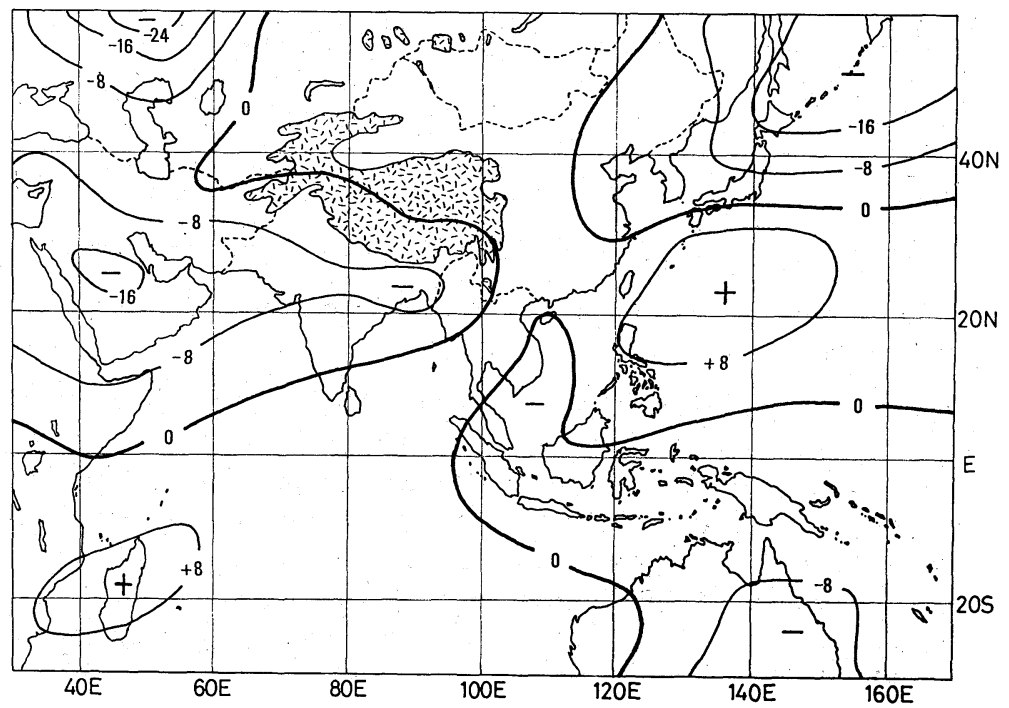

Fig. 4 Difference in the $850 \mathrm{mb}$ geopotential height in June. Positive values indicate increases in the geopotential height when the TEJ is strong. (Unit: geopotential meters). 


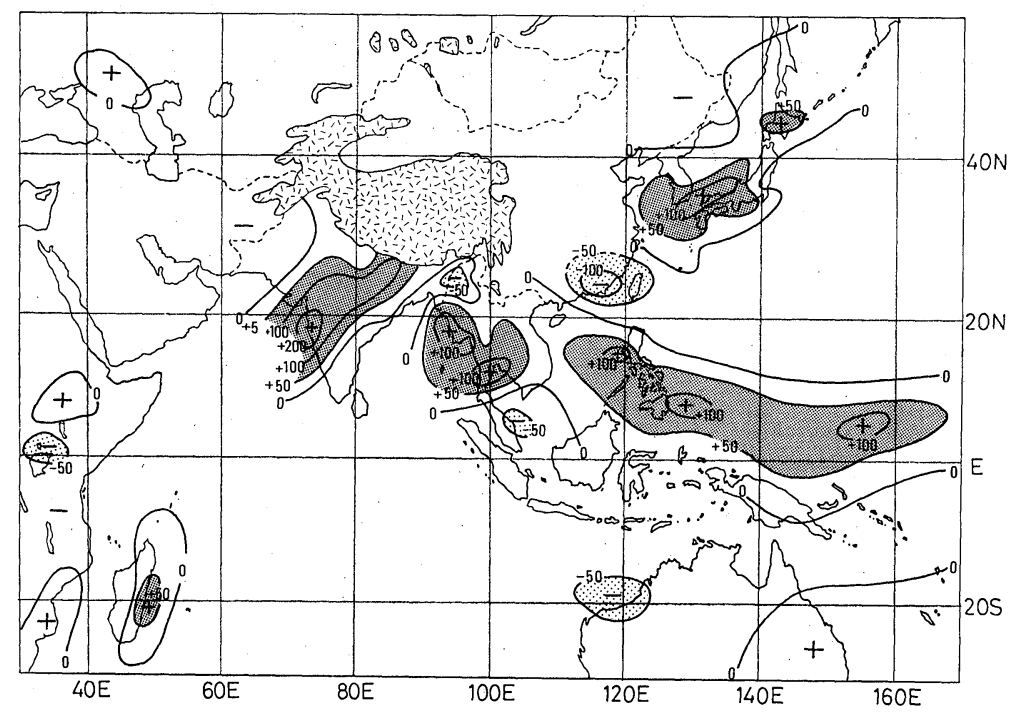

Fig. 5 Difference in the precipitation in June. Positive values indicate increases in the precipitation when the TEJ is strong. (Unit: $\mathrm{mm}$ )

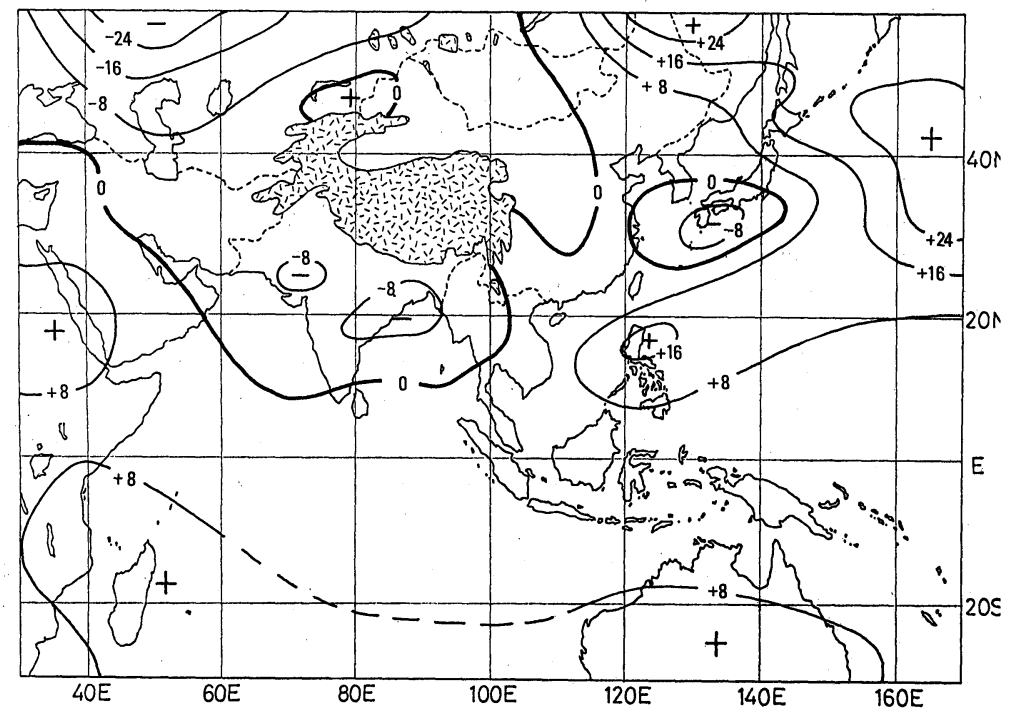

Fig. 6 Same as Fig. 4 but for July. (Unit: geopotential meters)

cipitation regions when the TEJ is strong. In strong TEJ years (see Table 1), the monsoon rain is heavy in India. Heavy orographic precipitation is observed in Burma and southern Thailand. The ITCZ is active near Micronesia. In the higher northern latitudes, the Baiu rain is heavy in southern Japan.

In July, the cyclonic circulation at the $850 \mathrm{mb}$ level reaches its peak intensity in the Indian subcontinent. The intensity of the TEJ also reaches its maximum development in July and
August. Moreover the interannual fluctuations of the TEJ are less than the other months in the summer (compare each month in Figures2 and 3). The break monsoon in India is also less frequent in July (Ayyar et al., 1973). When the TEJ is strong, the $850 \mathrm{mb}$ geopotential height is low in India (Figure 6). The pattern in Figure 6 is rather patchy outside of India. This is probably a consequence of the small amplitude of the fluctuations of the TEJ in July. In the higher northern latitudes, the $850 \mathrm{mb}$ geopotential height 


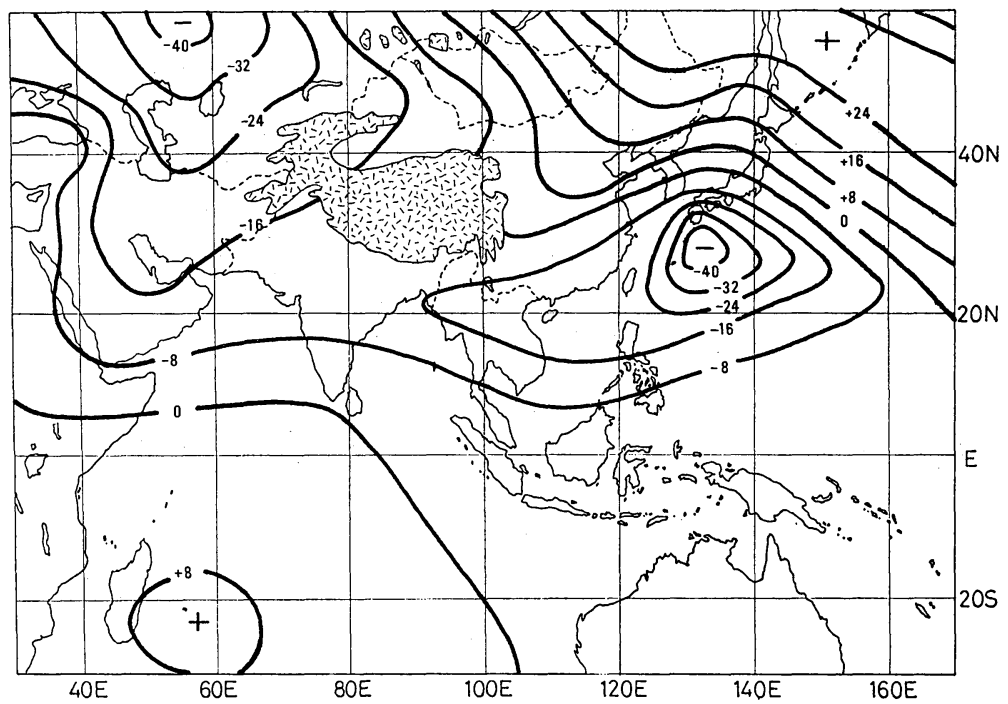

Fig. 7 Same as Fig. 4 but for August. (Unit: geopotential meters)

is high to north of the Caspian Sea when the TEJ is weak.

In August, the $150 \mathrm{mb}$ easterly wind (eastern portion of the TEJ) reaches its peak intensity near the longitudes of the Philippines. The ITCZ penetrates deep in to Micronesia and the typhoon activities reach their seasonal maximum. As a consequence of these typhoon activities, the change in the $850 \mathrm{mb}$ circulation regime was found to be extremely large to the east of $100^{\circ} \mathrm{E}$ (Figure 7). A large drop of the geopotential height (when the TEJ is strong) centered south of Kyushu is a result of the existence of slow moving typhoons near Okinawa. The outflow at the high level of this circulation helps to maintain the strong TEJ. When the TEJ is weak, anticyclonic circulation associated with the western extension of the Pacific high is observed near Okinawa. In the other regions, a broad area from India to western Micronesia experiences a strong southwest monsoon flow at the $850 \mathrm{mb}$ level when the TEJ is strong. In the higher northern latitudes, the pattern in Figure 7 is similar to the ones in June and July.

The relationship between the typhoons and the southwest monsoon was recently investigated by the following papers: Krishnamurti et al. (1977) examined the mean sea level pressure along latitudes $20^{\circ} \mathrm{N}$ for 44 years during June-September, and showed that the formation of monsoon depressions are preceded by a very slow westward propagating wave group initiated by a typhoon from the western Pacific. However Saha et al. (1981) have shown that there are many cases of much faster phase propagation of the disturbances (including the tropical depressions) across the Indochina peninsula (near $20^{\circ} \mathrm{N}$ ) which subsequently regenerated as a monsoon depression in Bay of Bengal. These studies have shown that the typhoons and tropical depressions which move westward near $20^{\circ} \mathrm{N}$ exerts a strong influence on the activities of the summer monsoon. In the current study, the typhoons which move slowly near Okinawa $\left(25-30^{\circ} \mathrm{N}\right)$ were also found to influence the TEJ through their high level outflow.

Figure 8 shows the difference in the precipitation in August. In most of India and the west coast of Indochina, heavy precipitation is observed when the TEJ is strong. The heavy precipitation along the southern coast of Japan is a result of frequent typhoon activities.

In September, the summer monsoon circulation slowly retreats from the south Asian region. When the TEJ is strong, the pattern of decrease in the $850 \mathrm{mb}$ geopotential height in India (not shown) is same as the previous three months. The major change from August is the development of ridge near Japan in a region defined by $25^{\circ} \mathrm{N}$ to $45^{\circ} \mathrm{N}$ and $125^{\circ} \mathrm{E}$ to $135^{\circ} \mathrm{E}$. This positive anomaly is a result of the landing of the major typhoon in Japan in September with weak TEJ. This tendency show that the middle latitude circulation influences the track of the ty- 


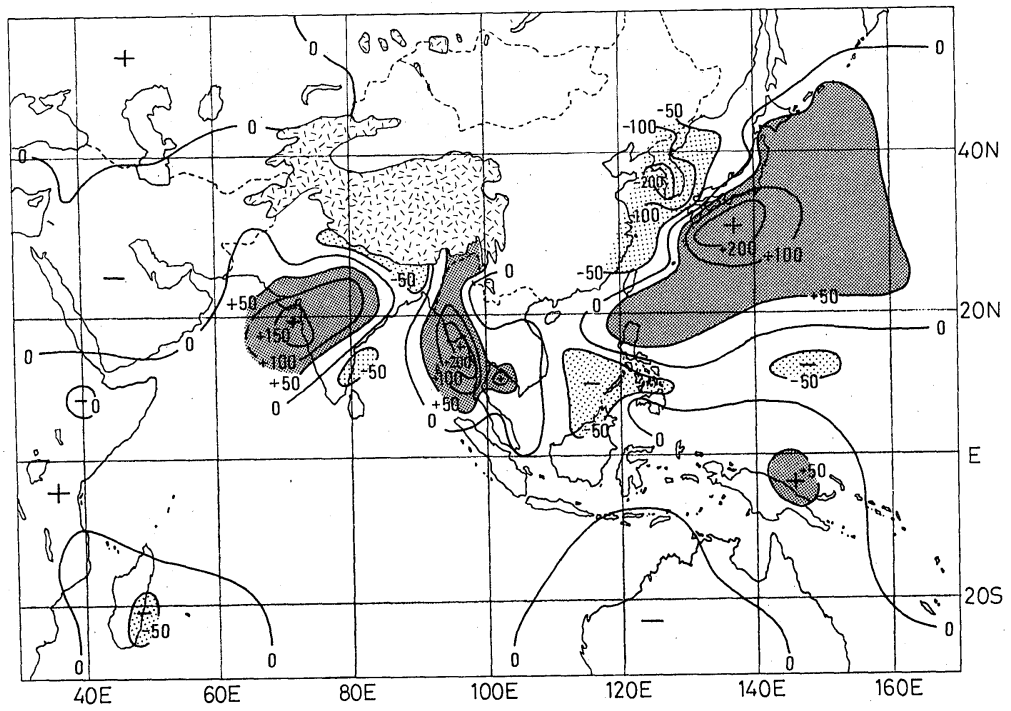

Fig. 8 Same as Fig. 5 but for August. (Unit: mm)

phoons and the monsoon circulations. These interaction will be discussed in the next section.

\section{Relationship to the middle latitude circulation and the Walker circulation}

In the previous section, evidence has been shown that when the TEJ is weak, there exists a pronounced area of high geopotential height at the $850 \mathrm{mb}$ level near the Caspian Sea. For this reason, the $500 \mathrm{mb}$ circulation in the middle and high northern latitudes was investigated by the same method which was described at the end of section 2. The results show that in July and August, interaction between the middle latitude circulation and the TEJ is strong. Figure 9 shows the difference in the $500 \mathrm{mb}$ geopotential height in July. When the TEJ is weak, there is a pronounced area of high geopotential height to the north of the Caspian Sea and the area of low geopotential height near $120^{\circ} \mathrm{E}$ (along $50^{\circ} \mathrm{N}$ ). When the TEJ is strong, the subtropical jet stream near $40^{\circ} \mathrm{N}$ is strong to the west of Himalayas and meanders south near $120^{\circ} \mathrm{E}$. The regions of highest correlation of the $500 \mathrm{mb}$ geopotential height to the fluctuations of the TEJ are located at $50^{\circ} \mathrm{E}(+0.84 ; 1964-1977)$ and at $50^{\circ} \mathrm{N}, 40^{\circ} \mathrm{E}(-0.56 ; 1964-1977)$.

In August, the pattern near $50^{\circ} \mathrm{N}$ is similar to July (Figure 10). The regions of highest correlation of the $500 \mathrm{mb}$ geopotential height to the fluctuations of the TEJ are located at $50^{\circ} \mathrm{N}$, $50^{\circ} \mathrm{E}(-0.65 ; 1964-1977)$. The response of the subtropical jet stream is different from July to the east of Himalayas. When the TEJ is strong, the subtropical jet is displaced north of its normal position from the longitude of $120^{\circ} \mathrm{E}$ to $160^{\circ} \mathrm{E}$ by the area of high geopotential height extending from Lake Baikal to the Pacific Ocean near $40^{\circ} \mathrm{N}, 160^{\circ} \mathrm{E}$.

The occurrence of the area of high geopotential height at the $500 \mathrm{mb}$ level to the north of the Caspian Sea (when the TEJ is weak) suggests the formation of the blocking high in this region. Figure 11 shows the zonal cross-section of the $500 \mathrm{mb}$ geopotential height at $50^{\circ} \mathrm{N}$ for August. When the TEJ is weak (thin dashed line), there exists a pronounced blocking ridge at $50^{\circ} \mathrm{E}$ and below normal geopotential height to the east of $90^{\circ} \mathrm{E}$. An inspection of the individual August showed that this blocking ridge was most intense in 1972 and 1979 (these are the years with major break monsoon in India). In these two Augusts, the $500 \mathrm{mb}$ geopotential height at $50^{\circ} \mathrm{N}, 50^{\circ} \mathrm{E}$ exceeded 5800 geopotential meters. All four Augusts (see Table 1) used for the composite map of weak TEJ showed above normal geopotential height at $50^{\circ} \mathrm{N}, 50^{\circ} \mathrm{E}$. The blocking high have developed near $50^{\circ} \mathrm{N}, 50^{\circ} \mathrm{E}$ in 1969 and 1976 (in addition to 1972 and 1979).

Ramaswamy and Pareek (1978) showed that a trough in the middle latitudes exists at $110^{\circ} \mathrm{E}$ in both hemispheres when the break monsoon condition prevails in India. In the current study Figures 4, 6, and 7 show that the $850 \mathrm{mb}$ southwest monsoon circulation in India is weak when the TEJ is weak. In addition, Figures 5 and 8 


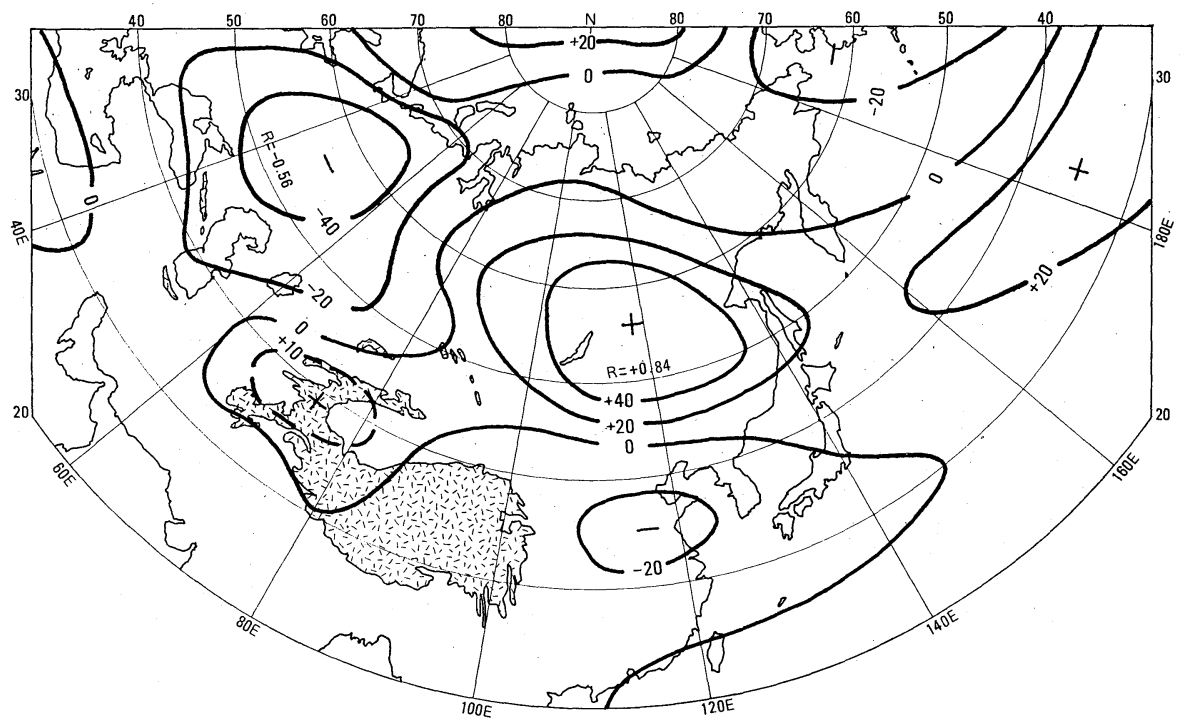

Fig. 9 Same as Fig. 4 but for the $500 \mathrm{mb}$ level in northern middle latitude in July. (Unit: geopotential meters)

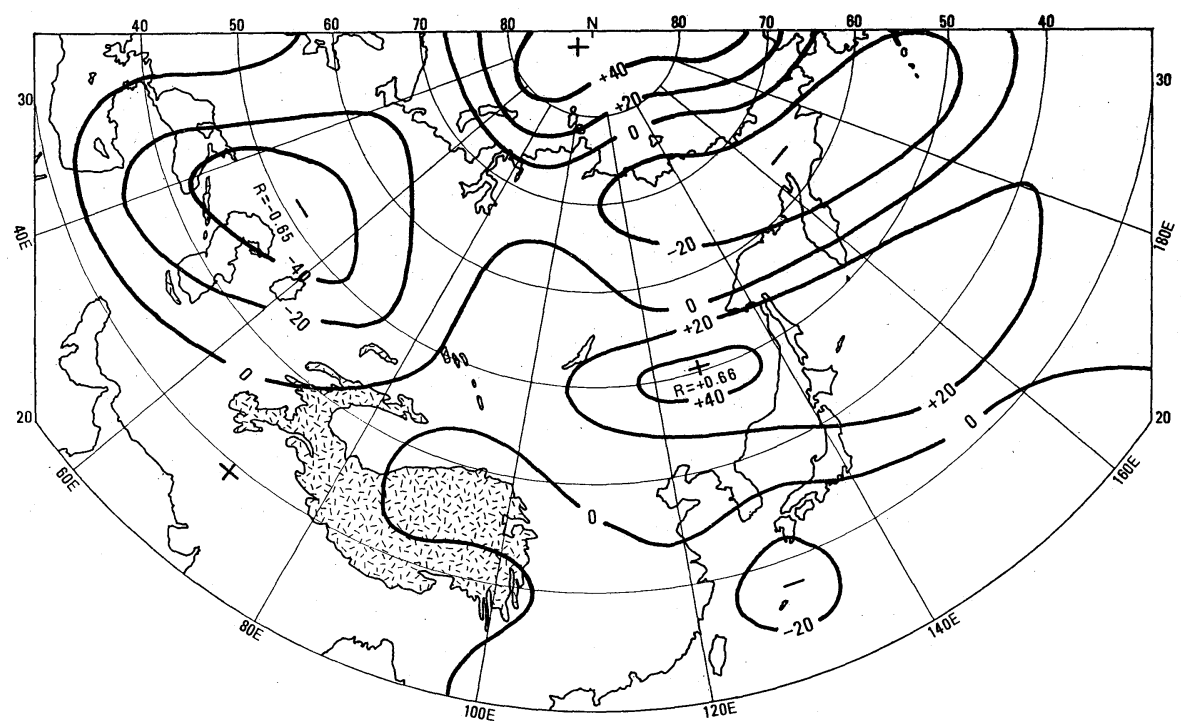

Fig. 10 Same as Fig. 4 but for the $500 \mathrm{mb}$ level in northern middle latitudes in August. (Unit: geopotential meters)

show that the precipitation tends to decrease in India when the TEJ is weak. Hence the break monsoon condition is more likely to develop when the TEJ is weak. In the current study, the area of increased $500 \mathrm{mb}$ geopotential height is located to the west of $90^{\circ} \mathrm{E}$ with decreased heights near $120^{\circ} \mathrm{E}$ and $130^{\circ} \mathrm{E}$ (Figures 9, 10) when the TEJ is weak. This location is about $10-15^{\circ}$ east of the previous investigation.

When the TEJ is strong (thick dashed line in
Figure 11) the pattern of the geopotential height is flat (at $50^{\circ} \mathrm{N}$ ) showing a zonal flow pattern (high index). The northward displacement of the Pacific subtropical high near Japan indicates southeasterly wind up to $35^{\circ} \mathrm{N}$ at the $850 \mathrm{mb}$ and $500 \mathrm{mb}$ level near the longitude from $130^{\circ} \mathrm{E}$ to $160^{\circ} \mathrm{E}$ (Figures 7 and 10 ). This condition is favorable for the occurrence of slow moving typhoons near Okinawa.

Yasunari (1981) has suggested that the middle 


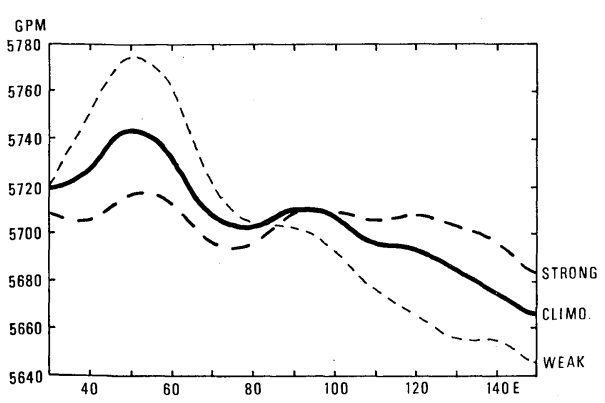

Fig. 11 Zonal cross-section of the $500 \mathrm{mb}$ geopotential height at $50^{\circ} \mathrm{N}$ for August. The thick solid line is the average for a 17-year period (1964-1980). Thick (thin) dashed line is the average for 4 August with strong (weak) TEJ. See Table 1 for the years with strong (weak) TEJ.

latitude circulation in the southern hemisphere plays an important role in the 30 to 40 day oscillation of the monsoon. In the current study, no detailed study of this interaction was conducted because the data over the South Indian Ocean was not adequate. However, an inspection of the $850 \mathrm{mb}$ geopotential height over Madagascar shows that when the TEJ is strong the height is above normal. This pattern is observed in June, July, and August. This suggests a warm period with high index circulation (zonal flow in the middle latitudes) when the TEJ is strong. This coincides with the active monsoon phase in India in the schematic model suggested by Yasunari (1981).

The relationship to the Walker circulation was extensively investigated since Walker and Bliss (1937). Recently, Quinn (1974), Kidson (1975), and Wyrtki $(1975,1977)$ investigated the relationship between the Walker circulation and El Nino.

In the current study, the interannual fluctuations of the TEJ were compared to the El Nino component of the sea surface temperature in the Pacific Ocean (Weare et al., 1976). The correlation between the TEJ (average of four summer months) and the 5 month average of sea surface temperature centered on July was -0.55 (1964-1973). This suggests that the Walker circulation alone is not sufficient to explain the interannual fluctuations of the TEJ. However, the years with major El Nino (1965, 1972, 1976) were found to be the years with very weak TEJ. In most of the other years, the influence of the middle latitude circulation are probably more important upon the strength of the TEJ.

\section{Summer monsoon circulation during the MONEX year}

In this section, 1979 MONEX summer monsoon circulation was compared to the circulation in the recent years. Figure 12 shows the $150 \mathrm{mb}$ wind speed at $10^{\circ} \mathrm{N}$ (TEJ) from June to September for a period from 1964 to 1980. The TEJ in the MONEX summer $\left(25.0 \mathrm{~ms}^{-1}\right)$ ranked 4th weakest monsoon in the last 17 years. Figures 2 and 3 show that the TEJ in 1979 was weak in the every month of the summer except for July.

Figure 13 shows the percent of the normal precipitation (1951-1960 average) for the MONEX summer. In much of the south Asian region, monsoon rainfall was deficient. The drought near the Ganges valley was the worst since 1877 .

In the MONEX summer of 1979 , the monsoon circulation was established later than the normal. Figure 14 shows the departure from the normal of the $850 \mathrm{mb}$ geopotential height in June 1979. There is a large area of above normal height extending from the Black Sea to southern Japan. The height are mostly below normal near $10^{\circ} \mathrm{N}$. The southwest monsoon was weak and the monsoon rain in India was delayed by about 10 days.

After temporary strengthening in July, the TEJ was weak in August. The summer monsoon circulation was weak and a blocking high persisted to the north of the Caspian Sea (Figure 15). The Indian monsoon rainfall was well below normal in the second half of August. The area of below

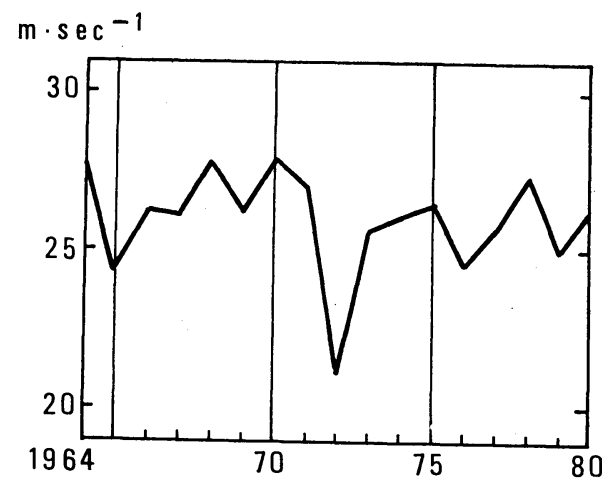

Fig. $12150 \mathrm{mb}$ wind speed at $10^{\circ} \mathrm{N}$ (TEJ) for the summer monsoon season (June to September) for a pericd from 1964 to 1980. (Unit: $\mathrm{ms}^{-1}$ ) 


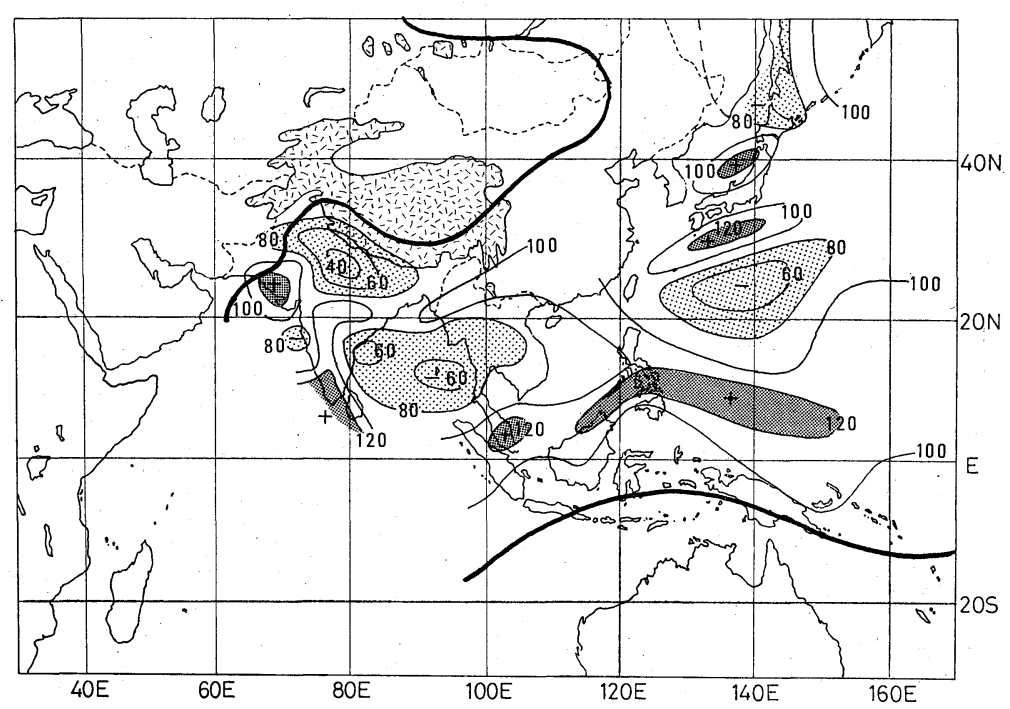

Fig. 13 Percent of 1951-1960 precipitation for the MONEX summer (June to September 1979). Thick lines are the limits of at least $200 \mathrm{~mm}$ of precipitation in summer (normal). Dark shaded regions are the areas with over 120 percent of the normal precipitation. Light dotted regions are the areas with less than 80 percent of the normal precipitation.

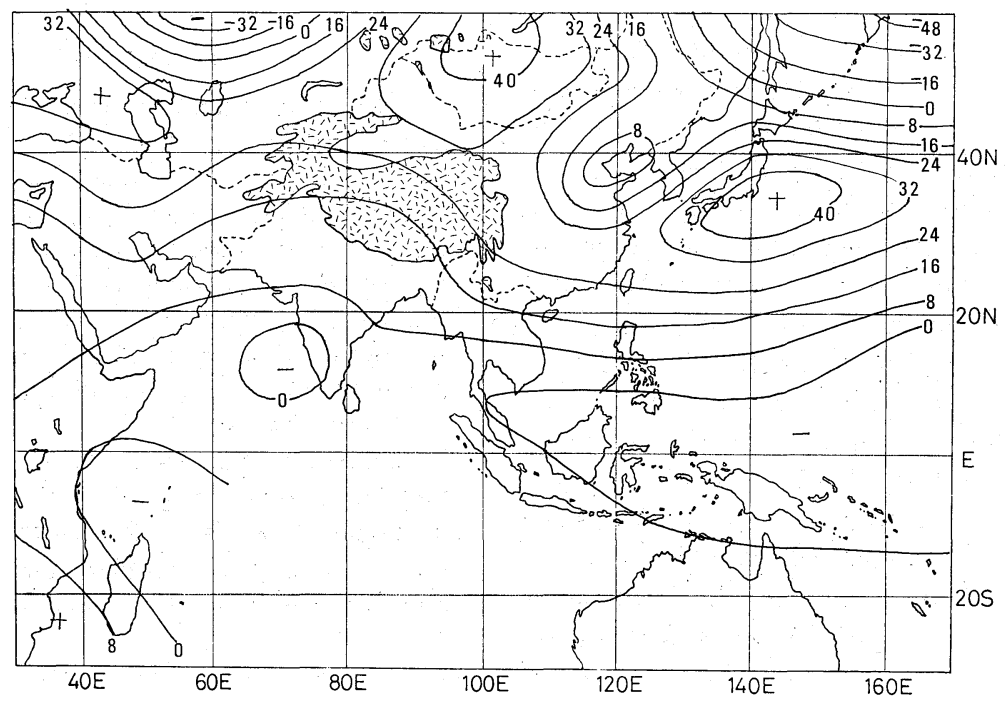

Fig. 14 Departure from the normal (1964-1975 average) $850 \mathrm{mb}$ geopotential height for June 1979. (Unit: geopotential meters)

normal height near Taiwan is a result of two typhoons taking almost same track over this area.

\section{Conclusion}

This study indicates a strong association of the interannual fluctuations of the summer mon- soon (TEJ) with the middle latitude circulation in the northern hemisphere. When the TEJ is strong, the circulation near $50^{\circ} \mathrm{N}$ is zonal. On the other hand, when the TEJ is weak, a blocking high develops to the north of the Caspian Sea and the area of below normal $500 \mathrm{mb}$ geopotential develops near $50^{\circ} \mathrm{N}, 120-130^{\circ} \mathrm{E}$. These 


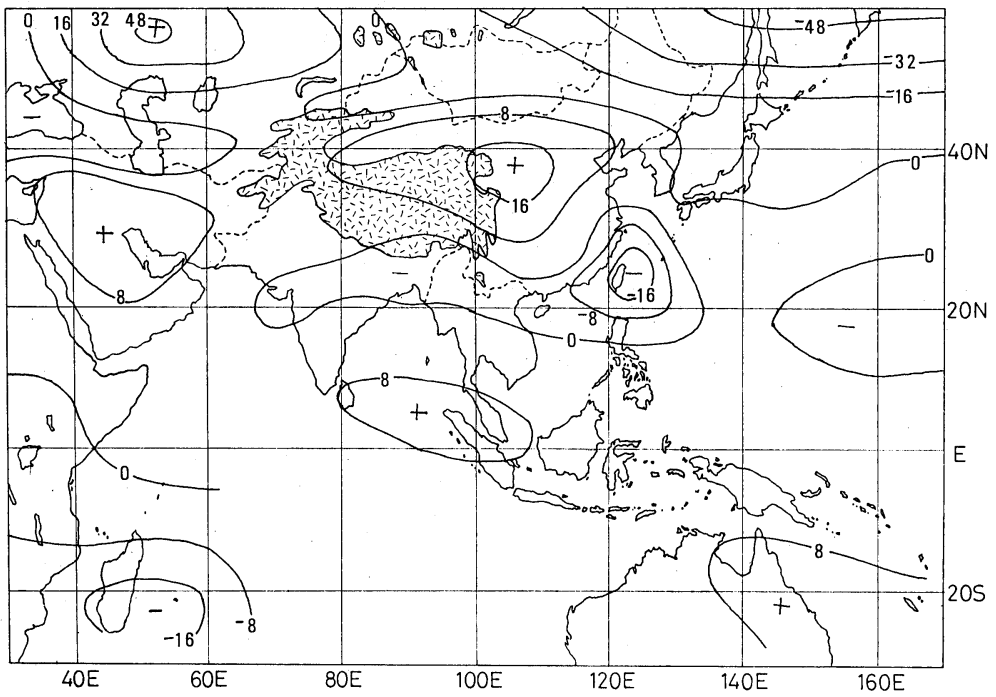

Fig. 15 Same as Fig. 14 but for August 1979. (Unit: geopotential meters)

interaction are best developed in July and August when the summer monsoon reaches highest northern latitudes. In the southern hemisphere, the zonal or high index circulation appears to coincides with strong TEJ.

In all four months of the summer monsoon with strong TEJ, the low level Indian monsoon circulation is strong. The precipitation when averaged over the entire Asian region south of $40^{\circ} \mathrm{N}$ were above normal. This shows that an increases in latent heat release coincides with strong TEJ. The typhoons near Okinawa play an important role in August. The strong outflow from these typhoons helps to maintain the strong TEJ.

In the 1979 MONEX summer, the TEJ was weak and drought was observed in the Ganges valley of India. Only 3 of the past 17 summers had weaker TEJ (1965, 1972, and 1976) compared to the MONEX summer. Except for these years with major $\mathrm{El} \mathrm{Nino,} \mathrm{the} \mathrm{middle} \mathrm{latitude}$ circulation were more important in influencing the strength of the TEJ. In the years with major El Nino, the Walker circulation has strong influence on the summer monsoon and very weak TEJ are observed.

\section{Acknowledgements}

The author is grateful to Dr. Masatoshi M. Yoshino of the Institute of Geoscience for many helpful suggestions and encouragements. In addition, the author is deeply indebted to Mr. M. Sato and Mr. F. Ichiminami for drawing the figures. Thanks are also due to Dr. Takeshi Kawamura and the other members of the Insti- tute for many helpful suggestions. The author is very grateful for the constructive comments offered by the reviewers of the Journal. Part of this paper is a doctor thesis conducted at the University of Tsukuba.

\section{References}

Ayyar, H., M. R. Nagasubramanin, and T. G. Changraney, 1973: Rainfall and floods/droughts in India during the 1972 southwest monsoon period. Indian J. Meteor. Geophys., 24, 215-222.

Flohn, H., 1964: Investigations on the tropical easterly jet. Bonner Meteor. Abhandl., 4, 1-83.

Kanamitsu, M., and T. N. Krishnamurti, 1978: Northern summer tropical circulations during drought and normal rainfall months. Mon. Wea. Rev., 106, 331-347.

Keshavamurti, R. N., 1968: On the maintenance of the mean zonal motion in the Indian summer monsoon. Mon. Wea. Rev., 1c0, 383-388.

Kidson, J. W., 1975: Tropical eigenvector analysis and the Southern Oscillation. Mon. Wea. Rev., 103, 187-196.

Kobayashi, N., 1974: Interannual variations of tropical easterly jet stream and rainfall in south Asia. Geophys. Mag., 37, 123-134.

Koteswaram, P., 1958: The easterly jet stream in the tropics. Tellus, 10, 43-57.

Krishnamurti, T. N., 1971: Tropical east-west circulation during the northern summer. J. Atmos. Sci., 28, 1342-1347.

Krishnamurti, T. N., J. Molinari, H. L. Pan, and V. Wong, 1977: Downstream amplification and formation of monsoon disturbances. Mon. Wea. Rev., 195, 1281-1297.

Newell, R. E., J. W. Kidson, D. G. Vincent, and 
G. J. Boer, 1972: The general circulation of the tropical atmosphere and interactions with extratropical latitudes., vol.1, M.I.T. press, 258.

Quinn, W. H., 1974: Monitoring and predicting El Nino invasions. J. Appl. Meteor., 13, 825-830.

Ramaswamy, C., and R. S. Pareek, 1978: The southwest monsoon over India and its teleconnections with middle and upper tropospheric flow patterns over the southern hemisphere. Tellus, 30, 126-135.

Saha, K., F. Sanders, and J. Shukla, 1981: Westward propagating predecessors of monsoon depressions. Mon. Wea. Rev., 109, 330-343.

Walker, G. T., and E. W. Bliss, 1932: World Weather, V. Mem. of the Roy. Meteor. Soc., IV, 53-80.
1937: World Weather VI. Mem. of the Roy. Meteor. Soc., IV, 119-139.

Weare, B. C., A. R. Navato, and R. E. Newell, 1976: Empirical orthogonal analysis of Pacific sea surface temperatures. J. Phys. Oceanogr., 6, 671-678.

Wyrtki, K., 1975: El Nino-the dynamic response of the equatorial Pacific Ocean to atmospheric forcing. J. Phys. Oceanogr., 5, 572-584. 1977: Sea level during the 1972 El Nino. J. Phys. Oceanogr., 7, 779-787.

Yasunari, T., 1981: Structure of an Indian summer monsoon system with around 40 day period. J. Meteor. Soc. Japan, 59, 336-354.

\section{アジア地域における夏のモンスーンと熱帯東風ジェットの年々の変動}

田 $\underset{\text { 筑波大学 }}{\text { 実 }}$

アジア地域に扣ける夏季モンスーンを 1964 年から 1980 年までの17年間について年々の変動を総観的に解析し た。150 mb 面付近で観測される熱帯東風ジェット(TEJ) の変動でモンスーンの強弱を表現した。

夏のモンスーンの変動は北半球の中緯度偏西風や台風の活動などの強い影響を受けていることがわかった。ュ ーラシア大陸で偏西風が東西流となり台風が 8 月に沖縄付近でゆっくりと北上すると TEJ が強くモンスーンが 活発となる。しかしカスピ海付近でブロッキング高気圧が出現するとモンスーンは弱くなる。 Walker Circulation は El Nino が出現した年には強い影響を拈よぼし，非常に弱いTEJ の夏になりやすい。最近の17年間で は 1965，1972，1976 年などがこのような年であった。1979 年の MONEX の夏はこれらの年につづいてモンス ーンが 4 番目に弱い年であった。 